\title{
THE PRECAUTIONARY APPROACH TO THE INSTALLATION OF TELECOMMUNICATION MASTS IN RESIDENTIAL AREAS IN NIGERIA: A LEGAL RESPONSE
}

\author{
Muhammad Kamaldeen Imam-Tamim * \\ Oluwadamilola Oyeyipo \\ Yahaya A. Alajo*
}

\begin{abstract}
The advent of Global System for Mobile Communication (GSM) in Nigeria has brought immense advantages to the social and economic activities in the country. Despite the various advantages, the installation of telecommunication masts and base stations in residential areas has led to anxieties, fears and debates about the possible adverse effects on human health as well as security of properties. Instead of addressing the fears, the telecommunication companies continue to install telecommunication masts and base stations in the residential areas unabated. The article assesses the impact of these installations on health and properties of the residents in order to consider the reality of the fears and examines Nigerian laws to find out whether there are regulations that control how telecommunication masts are to be installed in residential areas to prevent health and property threat to the inhabitants. The article employs both doctrinal and non-doctrinal approaches of the qualitative legal research method by analysing legal and relevant texts and by conducting site surveys as well as unstructured interviews with residents who live near telecom masts.
\end{abstract}

Keywords: Precautionary approach, environmental law, telecommunication installations, electromagnetic field radiation, environmental pollution

Corresponding Author, Ph.D. Researcher, Ahmad Ibrahim Kulliyyah of Laws, IIUM. Lecturer, Department of Private and Property Law, University of Ilorin. Email: lawyertamim@gmail.com. Phone: +234-7034499944

** $\quad$ LL.M. Student, University of Ilorin, Ilorin, Nigeria. Counsel, Lofty Heights Law Firm, Ilorin, Kwara State, Nigeria.

*** $\quad$ Alajo \& Associates, Ilorin, Kwara State, Nigeria. 


\title{
PENDEKATAN BERJAGA-JAGA UNTUK PEMASANGAN MENARA-MENARA TELEKOMUNIKASI DI KAWASAN PERUMAHAN DI NIGERIA: SATU MAKLUM BALAS PERUNDANGAN
}

\begin{abstract}
ABSTRAK
Kedatangan Sistem Global Komunikasi Mudah Alih (GSM) di Nigeria telah membawa banyak kelebihan kepada aktiviti sosial dan ekonomi di negara itu. Walaupun adanya kelebihan bermacam ini, pemasangan menara-menara telekomunikasi dan stesen pangkalan di kawasan perumahan telah menimbulkan kebimbangan, ketakutan dan perbahasan tentang kemungkinan kesan buruk terhadap kesihatan manusia dan keselamatan harta benda. Walaubagaimanapun, tanpa menangani ketakutan ini, syarikat telekomunikasi masih terus memasang menara-menara telekomunikasi dan stesyen pangkalan di kawasan-kawasan perumahan tanpa henti. Makalah ini menilai kesan pemasangan tersebut ke atas harta benda dan penduduk untuk menimbang realiti ketakutan. Makalah juga mengkaji undang-undang Nigeria untuk mengetahui samada terdapat undang-undang kecil yang mengawal bagaimana menara-menara telekomunikasi dipasang di kawasankawasan perumahan untuk menghalang ancaman kepada kesihatan dan harta benda penduduk. Makalah menggunakan kedua-dua, pendekatan doktrinal dan bukan doktrin, dalam metodologi perundangan kualitatif dengan menganalisa teks perundangan dan teks berkaitan dan juga menjalankan temuduga di lokasi dengan penduduk-penduduk yang tinggal berdekatan menara-menara telekomunikasi.
\end{abstract}

Kata Kunci: Pendekatan berjaga-jaga, undang-undang alam sekitar, pemasangan telekomunikasi, radiasi gelombang elektromagnetik, pencemaran alam sekitar 


\section{INTRODUCTION}

The relevance of effective means of communication in the globalisation process cannot be over emphasised. This importance of communication coupled with technological development generated the rapid growth experienced in the telecommunication industry in Nigeria and the world at large. ${ }^{1}$ It plays an increasingly important role in general commercial activity, becoming a big employer of labour, thereby making an indirect contribution to the national economy in Nigeria. ${ }^{2}$ However, as advantageous as the introduction of telecommunication is to Nigerians, there have been concerns about some negative impacts it portends for the environment. ${ }^{3}$ The extensive use of mobile phones has resulted in telecommunication masts and base stations springing up in every corner of Nigeria. This has now been accompanied by fears, anxieties and debates about the possible adverse effects on human health; complaints and protests over radiation, noise, vibration and fumes from attached generating sets by residents close to these masts are currently on the high side in Nigeria. $^{4}$

1 Alleman, J. et al., Telecommunications and Economic Development: Empirical Evidence from Southern Africa (Sydney: International Telecommunications Society, n.d.), 1-1, 1-3 and 2-1.

2 Ndukwe, E., "The latest government initiative to stimulate investment and private sector involvement", Nigerian Communication Commission, accessed October 16 ,

2015 , http://www.ncc.gov.ng/archive/speeches_presentations/EVC's\%20Presentation/ 2009/role_telecoms.pdf.; Awoleye, O. M., "Socio-Economic Effect of Telecommunication Growth in Nigeria: An Exploratory Study" Interdisciplinary Journal of Contemporary Research in Business 4, no. 2 (2012): 256-262.

3 Eneye, I. B., "The Health, Safety \& Environment Challenges of Mobile Telecommunication Infrastructural Deployment in Nigeria" (presentation, NCC's First West African Conference on Electromagnetic Fields Exposure and Health, Victoria Crown Plaza Hotel, Victoria Island, Lagos, Nigeria, Wednesday, $27^{\text {th }}$ and Thursday, $28^{\text {th }}$ June, 2012), 7; Opara S., "Telecoms Masts: NCC allays fears of residents", Nigerian Best Forum, Accessed October 16, 2015, http://www.nigerianbestforum.com/index.php?topic=29384.0;wap. ; Laplace, "Telecoms Masts: NCC allays fear of health risks", Laplace Technologies, Accessed October 16, 2015, http://laplacetechnologies.com/news/ telecoms-masts-ncc-allays-fear-of-health-risks/.

4 Olusola-Obasa B., "Help! Globacom's Generators are killing us slowly", The Punch, July 16, 2010, http://www.punchng.com/Articl.aspx ?theartic=Art201007171191839; Agency Reporter, "Help! Globacom's generators are killing us slowly", Nigerian Best Forum, Accessed October 16, 2015, http://www.nigerianbestforum.com/index.php?topic=81318.0. 
It seems however that the only consideration by the mobile telecommunication operators in Nigeria is 'qualitative service' rather than 'health implications' or 'safety' of neighbours and subscribers. The more people complain, the more new masts and base stations spring up in residential areas, prompting the urge to look into the hazards and feelings of the people near whom telecommunication masts and base stations are installed. In Nigeria today, mobile phone masts are found erected indiscriminately as if they are completely safe to human health. They are today found close to schools, churches, hospitals, mosques, offices, markets, roads and residential areas.

The article employs both doctrinal and non-doctrinal approaches of qualitative legal research method by analysing legal and relevant texts and by conducting site surveys and unstructured interviews with residents who live near telecom masts. The paper also uses the vertical comparative method to examine whether the Nigerian statutes on installation of telecommunication masts conform to the precautionary principle as prescribed by international instruments. The study shows that although Nigeria has some legal frameworks that encourage responsible use of the environment, there are certain inherent legal and regulatory institutional problems that prevent the effective implementation of these laws.

\section{EFFECTS OF INSTALLING TELECOMMUNICATION INSTALLATIONS IN RESIDENTIAL AREAS}

The utility of the modern Global System for Mobile Communication (GSM) network depends on other electrical, technological and mechanical facilities, which are generally described as the GSM network architecture. ${ }^{5}$ The GSM architecture is composed of several functional entities that interact together. ${ }^{6}$ These mainly include the Mobile Station (MS), Base Station Subsystem (BSS) and Network Subsystem (NSS), which use radio and microwave frequency

5 "GSM Architecture", Tutorials Point, accessed October 17, 2015, http://www.tutorialspoint.com/gsm/gsm_architecture.htm.; "GSM Network Architecture", Radio Electronics.Com, accessed October 17, 2015, http://www.radioelectronics.com/info/cellulartelecomms/gsm_technical/gsm_architecture.php.

6 "GSM Network Architecture", Radio-Electronics.com, ibid. 
technology to transmit signals in-between them. ${ }^{7}$ However, the functioning of these equipment also depends on other facilities like electric power generators, masts, electric cables, batteries, air conditioners, etc. All the aforementioned equipment contain different types of electrical, mechanical as well as organic and inorganic chemical components that have been reported in various studies as portending risks to human health. Some of the prominent environmental problems that could be attributed to the installation and operation of the telecommunication equipment include: hazardous materials and waste, emission of electromagnetic fields, air pollution and noise pollution.

\section{Hazardous Materials and Waste}

Operation and maintenance activities of base stations and other telecom facilities may also result in the generation of electronic wastes like circuit boards from computer and other electronic equipment. For instance, the operation of certain types of switching and transmitting equipment in Base Stations may require the use of backup power systems to keep the Base Station powered and functional at all times. ${ }^{8}$ This power backup system may consist of a combination of batteries (typically lead-acid batteries) and dieselfuelled backup generator sets. ${ }^{9}$ The operation and maintenance of backup generators and service vehicles may also result in the disposal of used tires, waste oils and used filters, while the electric transformer equipment and the refrigerants may contain hazardous chemicals like Polychlorinated Biphenyls (PCBs) and other potential ozone

7 Garg, V. K. and Wilkes, J. E., Principles and Applications of GSM (NJ, USA: Prentice Hall, 1998), 74-81; Scourias, J., "Overview of the Global System for Mobile Communication”, accessed May 5, 2003, http://ccnga.uwaterloo.ca/ jscouri/GSM/gsmreport.html.

8 Agency Reporter, "Help! Globacom's generators are killing us slowly".

9 Rozenblat, L., "The Basics of Backup Power: Reviews and Comparison of Different Systems for Home and Commercial Use", accessed October 17, 2015, http://www.smps.us/backuppower.html. 
depleting substances (ODSs) ${ }^{10}$ which have been considered to be injurious to human health and environment. ${ }^{11}$

\section{Emission of Electromagnetic Fields}

This issue is one of the most controversial in the telecommunication industries. This is due to the claims and counter-claims from experts that the emission of the electromagnetic fields constitute health challenges and dangers. As explained earlier, the mobile handset communicates with the Base Station through radiofrequency transmission signal involving microwave link. ${ }^{12}$ In the process of this signal transmission, radiation is emitted in the electromagnetic field (EMF). ${ }^{13}$ Radiation is the energy that comes from a source and travels through space and may penetrate various materials. ${ }^{14}$ It may be ionizing and non-ionizing radiation. ${ }^{15}$ Ionizing radiation also referred to as higher frequency radiation is generally considered to have harmful potentiality to human health when continuously exposed to for a very long time without adequate protection and or precaution. ${ }^{16}$ Non-Ionizing radiation on the other hand is the extremely low frequency radiation whose hazardous effect on human is still being

10 Lloyd's Register Marine, "A Guide to the Inventory of Hazardous Materials (IHM)", accessed October 17, 2015, http://www.lr.org/en/_images/.; International Finance Corporation,"Environmental, Health, and Safety Guidelines for Telecommunications", International Finance Corporation, accessed February 27, 2014 http://www.ifc.org/wps/wcm/connect.

11 Carpenter, D. O., "Polychlorinated Biphenyls and Human Health" International Journal of Occupational Medicine and Environmental Health 11, no. 4 (1998): 291-303; "Health and Environmental Effects of Ozone Layer Depletion", US Environmental Protection Agency, accessed October 17, 2014http://www3.epa.gov/ozone/science/effects/.

12 Garg and Wilkes, Principles and Applications of GSM, 74-81; Scourias, J., "Overview of the Global System for Mobile Communication".

13 Harris Corporation, Radio Communications in the Digital Age, $2^{\text {nd }}$ Ed., Vol. I (USA: Harris Corporation, 2005), 5.

14 CNSC, Introduction to Radiation (Ontario: Canadian Nuclear Safety Commission, 2012), 6; Folkers, C., "Radiation Basics", accessed October 17, 2015, https://www.nirs.org/radiation/radiationbasics.pdf.

15 CNSC, Introduction to Radiation, ibid.; Environmental Protection Agency, "Radiation Basics", Environmental Protection Agency, accessed October 17, 2015, http://www2.epa.gov/radiation/radiation-basics.

16 World Health Organisation, "Ionizing radiation, health effects and protective measures", Factsheet No. 371, November 2012, accessed October 17, 2015, http://www.who.int/mediacentre/factsheets/fs371/en/. 
debated among scientists Example of the non-ionizing radiation is the one used in the telecommunication industries.

The harmfulness of the emission of electromagnetic fields in the telecom industries to the environment has been a subject of debates since the market explosion in the industries. There are claims that the radiation emitted to the atmosphere in the telecom industries causes series of health challenges ranging from cancer, hampering of memory and sleep patterns, brain tumours, infertility, and anxiety, among others. ${ }^{17}$ This concern was acknowledged by the telecommunication industry regulators as a former Executive Vice Chairman of the Nigerian Communications Commission reportedly admitted that:

“...there are a myriad of health related concerns associated with EMF emissions from Mobile telecommunications. There has been growing concern throughout the developed world that exposure to radiation from base stations and mobile handsets could lead to increased risk of illnesses such as cancer and may adversely affect cognitive functions like concentration and may cause memory loss, headaches, dizziness and epilepsy among others" 18

This claim has been identified as a factor responsible for the attitudinal change in the operators' prospective and existing landlords and neighbours to now either resist or reject the requests to locate mobile telecoms equipment/infrastructures in and around their premises. ${ }^{19}$ The recent classification of electromagnetic fields (EMF) and radiofrequency $(\mathrm{RF})$ as possible causes of cancer to human

17 Yan J. G. 1., et al., "Effects of cellular phone emissions on sperm motility in rats" Fertility and Sterility, 88, no.4 (2007): 957-964; Rinat, Z., "Study: Cell Phones Damage Sperm Cells", Haaretz, accessed October 17, 2015, http://www.haaretz.com/print-edition/news/study-cellphones-damage-spermcells-1.282176.; Aginam, E., "Mobile phone mast allergy increases...as NCC allays fears over dangers", Vanguard, May 4, 2009; Ogundipe, S. and Obinna, C., "Nigerians ignore hazard of cell phone use", Vanguard, April 19, 2008.

18 Ndukwe, E., "A Keynote Address" (presentation, Workshop on Electromagnetic Compatibility Problems in Industrial and Commercial Installations/Equipment, University of Lagos, June 27, 2005), 1, accessed October 17, 2015,http://www.ncc.gov.ng/archive/speeches_presentations/EVC's\%20Present ation/EVC's\%20Paper\%20Electromagnetic\%20compatibility $\% 20$ problems $\% 20$ at $\% 20$ University\%20of\%20Lagos.pdf.

19 Eneye, "The Health, Safety \& Environment Challenges of Mobile Telecommunication", 7. 
beings by the International Agency for Research on Cancer (IARC), in May 2011 is surely lending credence to the concerns of people who believe radiation causes health risks. ${ }^{20}$

\section{Environmental Pollutions}

Several instances have been reported in the Nigerian newspapers where fumes emitted by generators have caused the death of entire families through inhalation of carbon monoxide. ${ }^{21}$ As at $31^{\text {st }}$ December, 2014, Nigerian GSM telecommunication companies were reported to have an accumulation of 30,176 base station sites ${ }^{22}$ of which more than $80 \%$ of them are powered by diesel fuelled generators with each BTS site requiring between 2,000 - 6,000 litre capacity storage facilities. ${ }^{23}$

20 IARC classifies Radiofrequency Electromagnetic Fields as possibly carcinogenic to humans. See "Press Release $\mathrm{N}^{\mathrm{o}}$ 208", Media Centre- IARC Press Release, accessed October 17, 2015, http://www.iarc.fr/en/mediacentre/pr/2011/index.php.

21 Umukoro, A., "Living with fumes of Death: More Nigerians dying from inhaling generator fumes", The Punch, accessed May 5, 2014, http://www.punchng.com/feature/living-with-fumes-of-death-more-nigeriansdying-from-inhaling-generator-fumes/.; Ogundipe, S., "Portable generators: Standby power or standby death?", Vanguard, October 9, 2013, http://www.vanguardngr.com/2013/10/portable-generators-standby-powerstandby-death/.; Olufowobi, S., "Over 10,000 Nigerians killed by generator fumes - Report", Odili.net, August 5, 2014, accessed October 17, 2015, http://odili.net/news/source/2014/aug/5/815.html.

22 Nigerian Communications Commission, 2014 Year End Subscriber/ Network Data Report for Telecommunications Operating Companies in Nigeria (Abuja: Nigerian Communications Commission, 2015), 10.

23 Eneye, "The Health, Safety \& Environment Challenges of Mobile Telecommunication", 7 . 


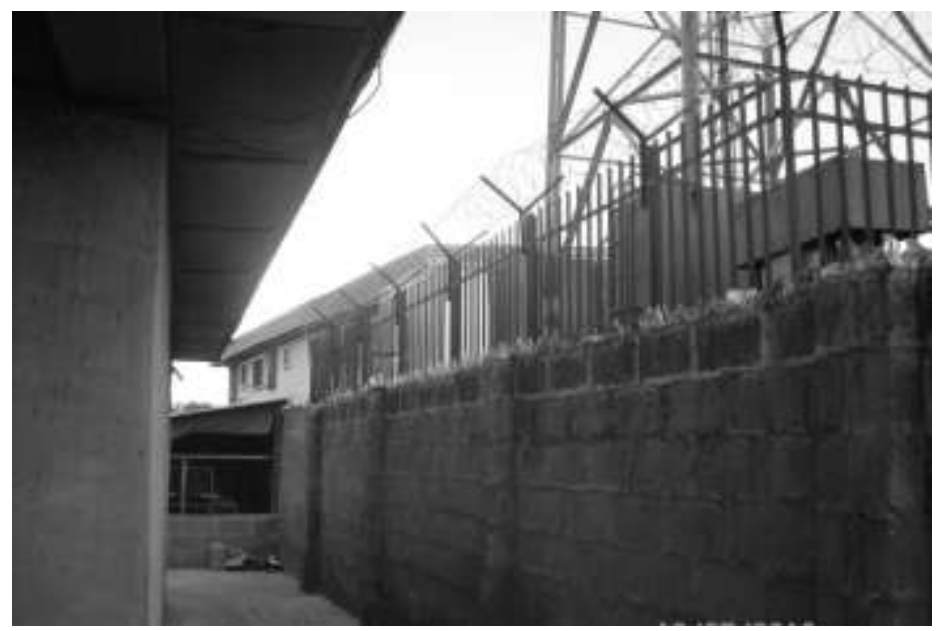

Figure 1: set of generators in a base station near a building at No. 10, Oke-Onigbin Street, Tanke, Ilorin, Kwara State, Nigeria. ${ }^{24}$

In the mast site shown in figure 1, the two generators are so close to the residential building that the occupants of the building remain sleepless, night and day and cannot open bedroom windows even in harsh weather for fear of fumes emanating from the generators, which are so strong that they impair the breathe of the residents. ${ }^{25}$

\section{Vibration and Noise Pollution}

Placing telecommunication installations in residential areas could also cause environmental pollutions. The emission of radiation into the air as already explained in the preceding paragraphs constitutes air

Source: Authors. The picture was taken by the authors while on site visits.

25 Pastor O. O., (living beside a telecom mast) Interview by Oluwadamilola Oyeyipo, Ilorin, Kwara State, November 26, 2013. A medical study of some deaths in the city of Port Harcourt, Nigeria found that about 75 persons were killed by carbon monoxide inhaled from generator fumes between December 2004 and January 1995. See Seleye-Fubara, D., et al., "Pathology of deaths from carbon monoxide poisoning in Port Harcourt: an autopsy study of 75 cases" Nigerian Journal of Medicine 20, no. 3 (2010): 337-340. See also Adeyemi, E. E., "Demystifying Air Pollution Challenges in Nigeria: A study of gasoline generator emissions and the impacts on ambient air quality", Academia.Edu, accessed October,

17 , 2015, https://www.academia.edu/7247644/Demystifying_air_pollution_challenges_in_ Nigeria_A_study_of_gasoline_generator_emissions_and_the_impacts_on_ambi ent_air_quality. 
pollution. ${ }^{26}$ Similarly, the erratic power supply in Nigeria requires the use of power generating sets as energy backup to power the telecom installations. In the operation of the power generating sets, fumes are released to the atmosphere while the generating sets also make unpleasant continuous noise thus, constituting both air and noise pollutions. The generators which are run for almost 24 hours a day are the source of noise from the base station and the noise with the usage and age of the generator. ${ }^{27}$ Noise is a nuisance to the environment, causing sleeplessness that may result in tragic consequences such as high blood pressure, stroke, concentration difficulties, fatigue, stress, and impairment of hearing. ${ }^{28}$ Fatigue and stress are symptoms known to be capable of precipitating various diseases including neuropsychiatry problems. ${ }^{29}$

The International Finance Corporation (IFC) of the World Bank has recommended the location of noise generating sources away from residential areas or other noise sensitive receptors in order to meet the noise emission levels provided in the General Environmental, Health and Safety Guidelines. ${ }^{30}$ Noise constitutes a nuisance to the residents and is an undue interference with their private life and peaceful enjoyment of his/her possessions thus affecting their general wellbeing. ${ }^{31}$

26 US EPA, “Air and Radiation”, US Environmental Protection Agency, accessed October 17, 2015, http://www3.epa.gov/air/airpollutants.html.

Mrs. H. A. (housewife who lives in a house near which a telecom base station has been installed), Interview by Imam-Tamim, Muhammad Kamaldeen, Ilorin, Kwara State, Nigeria, January 12, 2015. .

Stewart, W. et al., Mobile Phones and Health (Oxon, UK: National Radiological Protection Board, 2000), 1.

29 Akintonwa A., et al., "The Hazards of Non-Ionizing Radiation of Telecommunication Mast in an Urban Area of Lagos, Nigeria" African Journal of Biomedical Research 12, no. 1 (2009): 31-35; Santini R, et al., "Investigations on the health of people living near mobile telephone relay stations: Incidence according to distance and sex" Pathol Biol. 50, no. 6 (2002): 369-373; Abdel-Rassoul, G, et al., "Neurobehavioral effects among inhabitants around mobile phone base stations" Neurotoxicology 28, no. 2 (2007): 434-40. For other studies on the harmful effects of telecommunication masts, see "Studies of health effects of mobile phone masts", Wiredchild, accessed October 17, 2015, http://wiredchild.org/component/content/article/46-hidden/77-phonemast-studies.html.

30 International Finance Corporation, "Environmental, Health, and Safety Guidelines for Telecommunications"

31 See Rayner v UK (1986) 47 DR 5. See also Baggs v UK App. no. 9310/81 (1985) 44 DR 13. 
An adverse effect of power generator(s) in a mast site located in residential areas is the massive vibration experienced by residents close to the base stations. Such vibration often becomes too much that nearby buildings start to vibrate including the floors of the house, the ceilings, windows, walls and even fence, leading to structural damage of the building. ${ }^{32}$ Vibration can cause the damage of equipment, electronic materials and even common household equipment, and this can cause serious anxiety in residents close to the source, which may result in sleeplessness and fear of imminent collapse of buildings on them. ${ }^{33}$ The effect of vibration on adjacent landed properties has long been recognised in the case of Sturges $v$ Bridgman. ${ }^{34}$ Figures 2 and 3 below illustrate structural damage caused to some physical properties as a result of the vibration from the generators built in nearby telecom base stations. I

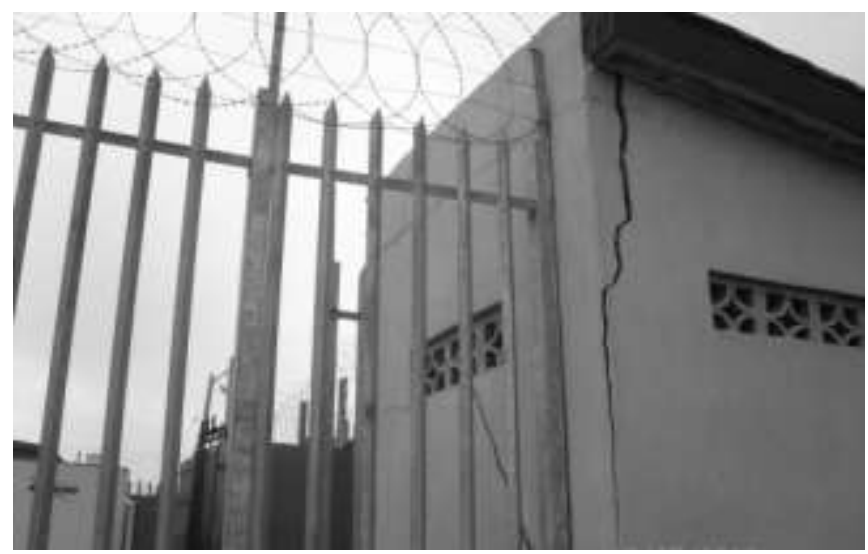

Figure 2: A mast site at Idofian, Ifelodun LGA, Kwara State showing the cracked wall of the Plant Room of the Base Station as a result of vibration from its generators. ${ }^{35}$

32 Mrs. H. A. (housewife who lives in a house near which a telecom base station has been installed), Interview by Imam-Tamim, Muhammad Kamaldeen, Ilorin, Kwara State, Nigeria, January 12, 2015.

33 Findeis H. and Peters E., "Disturbing effects of low frequency sound emissions and vibrations in residential buildings" Noise Health 6 (2004): 29-35; "Effect of low frequency vibration on buildings", The Engineering Toolbox, accessed March 9, 2011,http://www.engineeringtoolbox.com/building-vibration-effectsd_1293.html.

34 (1879) LR 11 Ch D 852.

35 Source: Authors. The picture was taken by the authors while on site visits. 


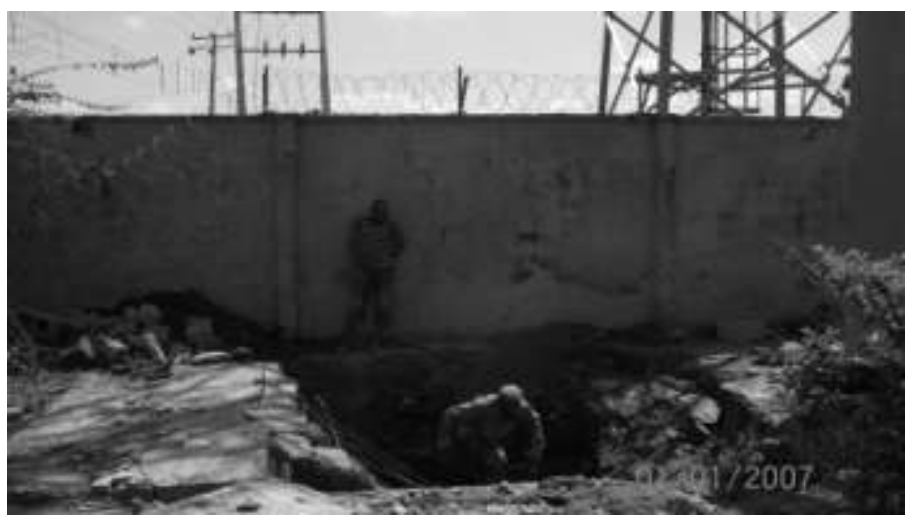

Figure 3: A collapsed septic tank at No 13 Sadiq Sulyman Street, Fate, Ilorin, Kwara State, Nigeria due to vibration of power generator in a close by telecom Mast site. ${ }^{36}$

Another adverse effect of an attached power generator to a base station is oil spillage. Sometimes there is uncontrolled spillage of oil from the attached power generators of a telecommunication mast, ${ }^{37}$ and if such occurs, the people around such masts may get their water polluted, especially well water, which is harmful to their health. No fewer than 125 incidents of ground water and land pollution cases have been recorded by the telecommunications operators over the last few years around the base station facilities. ${ }^{38}$ Between $5-10 \%$ of the incidents are due to either malfunctioning of the fuel flow regulators or functional failures, while $20-25 \%$ are deliberate acts by the neighbours or owners of such well water to attract compensation. ${ }^{39}$ The rest are caused by the unwholesome activities of vandals or thieves, who after vandalising the diesel lines and stealing the products, leave the lines open to flow freely into such water bodies and lands. ${ }^{40}$ The case of Engr. Charles Jimoh vs. Globacom Limited

Ezekiel, E., "FG shuts MTN Base Station over environmental breaches", The

Punch, August 24, 2010; Osadebamiren, P., "Telecoms Revolution and Environmental Sustainability", Summit Newspaper, July 21, 2011, 20; Ariyoosu, D. A., "An Examination of Legal Regulation and Environmental Impacts of Telecommunications Installations in Nigeria" Journal of Law, Policy and Globalisation 30 (2014): 88-96.

38 Eneye, "The Health, Safety \& Environment Challenges of Mobile Telecommunication", , 8 .

39

40

Ibid.

Ibid. 
$\& A n o r^{41}$ well demonstrates the negative effect of oil or fuel spillage, percolation and escape from telecommunication base stations to nearby residential premises. In this case, the claimant claimed that it was the diesel oil that escaped from the defendant's base station that percolated into his well and contaminated the water therein. This notwithstanding, the Nigerian courts have held in several other environment related cases that oil spill is an environmental hazard. In some of such cases like Shell Petroleum Development Company of Nigeria Limited v. Abel Isaiah and 2 others, ${ }^{42}$ and The Shell Petroleum Development Company (Nigeria) Limited. v.Councillor F. B. Farah ${ }^{43}$ the Nigerian courts, including the High Court, Court of Appeal and Supreme Court, unanimously agree to this position and awarded compensation in favour of the plaintiffs.

Following a series of complaints from residents, the National Environmental Standards and Regulations Enforcement Agency, ${ }^{44}$ shut an MTN base station over environmental breach, ${ }^{45}$ after carrying out some investigations and found out that apart from the fact that the base stations were too close to residential buildings, there was uncontrolled spillage of oil from the power generators, polluting the water used by residents. ${ }^{46}$

\section{Loss of Property's Value or Outright Loss of Property}

The presence of masts may result in loss of property values. Due to perceived fear of health hazards and possible collapse of the tall masts at any time without warning, properties close to masts are bound to lose attractiveness to prospective buyers or tenants, thereby losing value and this can lead to economic problems for some property owners. ${ }^{47}$ Tenants are found to have vacated their apartments on the

41 (Unreported) Suit No.: KWS/OM/21/2014. The matter is still pending before the High Court of Justice of Kwara State, holden at Omu-Aran judicial division.

42 (2002) 11 NWLR (Pt.723) p.168.

43 (1995) 3 NWLR Pt. 382 p. 145.

44 Hereinafter referred to as NESREA. The NESREA is the primary organisation saddled with the responsibility of monitoring the use of environment in Nigeria. It was created by the NESREA Act of 2007 to replace the Federal Environmental Protection Agency.

45 Ezekiel, "FG shuts MTN Base Station over environmental breaches", 17.

46 Ezekiel, ibid., 17.

47 Although some people who are financially conscious invite the telecom operators to bring in masts on their lands, but for people who are health conscious, properties with masts on it could lose attractiveness. 
claim that their health deteriorated since they moved into houses located very close to a telecom base station. ${ }^{48}$

The high rising masts could cause unimaginable damage if they collapse in residential areas as a result of structural defects or storms. ${ }^{49}$ Both humans and properties are not safe. Same is the case if they collapse on churches, mosques, offices, markets, schools, hospitals and roads around them. Cases of collapsed masts are being reported across Nigeria, an example is shown below in Figure $4 .{ }^{50}$

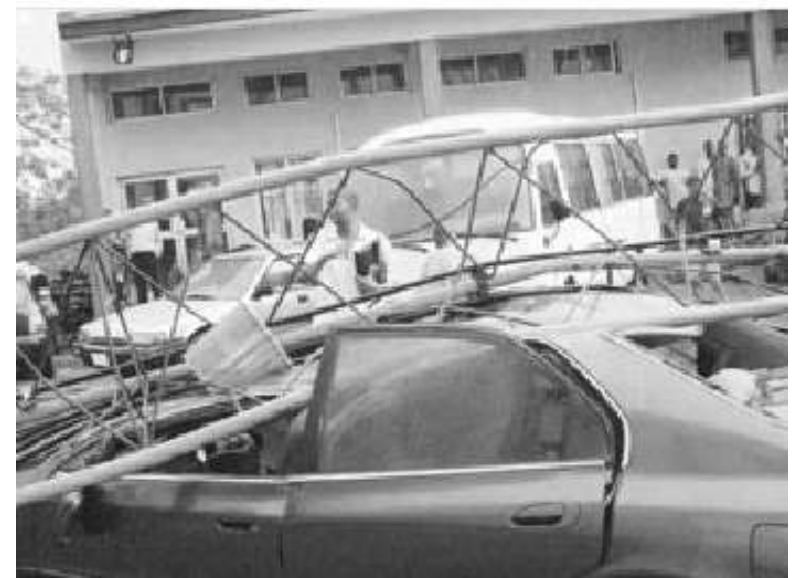

Figure 4: A mast fell on a car, destroying the car and probably killing the occupants $^{51}$

Similarly, the construction of the base station could result in alteration of the earth texture and consequently leading to collapse of nearby properties. While constructing the telecommunication installations such as mast towers or laying of cables, earth-moving

48 Mrs. H. A. (housewife who lives in a house near which a telecom base station has been installed), Interview by Imam-Tamim, Muhammad Kamaldeen, Ilorin, Kwara State, Nigeria, January 12, 2015; Mrs. A. S. (lives in a building near which a telecom base station has been installed), Interview by Imam-Tamim, Muhammad Kamaldeen, Ilorin, Kwara State, Nigeria, January 15, 2015.

49 See figure 4 below.

50 Ezekiel, E., "Erection of masts: NESREA goes tough on more Telecoms companies", The Punch, July 18, 2010, accessed July 19, 2010 http://www.punchontheweb.com/Articl.aspx?theartic=Art20100718445931.

51 Source: http://www.nigerianbestforum.com/generaltopics/erection-of-mastsnesrea-goes-tough-on-more-telecoms-companies/, accessed on October 17, 2015. 
equipment might be used, which have the tendency to loosen the surface of the earth texture. For instance, digging of land for laying linear cables could deface and loosen the earth ${ }^{52}$ while mounting of the tower in certain environment reduces its serenity. In the course of construction of a base station, access to public utility may also be temporarily denied.

\section{INTERNATIONAL COMMUNITY'S APPROACH TO INSTALLATION OF TELECOMMUNICATION MASTS AND BASE STATIONS AROUND RESIDENTIAL AREAS}

As Nigerians welcomed the advent of mobile telecommunications in year 2001, concerns were already being raised in some developed countries, especially in Europe, about the possible dangers and health hazards of living close to telecommunication masts. ${ }^{53}$ Some countries had started research to assess possible health effects arising from the use of mobile phones and living in close proximity to base stations. ${ }^{54}$ The countries began to consider some approaches towards preventing possible hazards and health risks from the installation of masts and base stations around residential premises. ${ }^{55}$ While some developed guidelines regulating approval and installation of masts, ${ }^{56}$ others placed a complete ban on installation of masts in their council areas pending the outcome of research. ${ }^{57}$ Some of the countries have

52 Jan Nemcik, et al., "Large excavations and their effect on displacement of land boundaries" (presentation, 12th Coal Operators' Conference, University of Wollongong \& the Australasian Institute of Mining and Metallurgy, 2012), 8.

53 Agbo J. U. and Nnadi, B., "Hazardous effects of EM Radiation from citing Mobile Phone masts close to Residential Houses and Schools" Pacific Journal of Science and Technology 11, no. 1 (2010): 455.

54 World Health Organization, "Electromagnetic Fields", World Health Organisation, accessed August 19, 2010, http://www.who.int/peh-emf/en.

55 Stewart, et al., Mobile Phones and Health, 1.

56 Barclay C., "Mobile Phones and Mobile Phone Masts", (RESEARCH PAPER 01/111 of $11^{\text {th }}$ December 2001), 21-25, accessed October 17, 2015, researchbriefings.files.parliament.uk/documents/RP01.../RP01-111.pdf.

57 New York Times, "World briefings: North Korea", New York Times, June 4, 2004, http://www.nytimes.com/; "North Korea recalls mobile phones" The Sydney Morning Herald. June 4, 2004 http://www.smh.com.au/articles; Lee, D., "North Korea: On the net in world's most secretive nation", bbc.co.uk., December 10 2012, accessed October 17, 2015, http://www.bbc.com/news/technology-20445632. 
ordered the removal of telecommunication masts because of perceived risks of cancer. ${ }^{58}$

The most imminent concern about the health impact of telecommunication base stations is the exposure to electromagnetic radiation emitted by the antennae of telecommunication masts. There are two types of radiation: ionising and non-ionising radiation. ${ }^{59}$ Ionising radiation are the electromagnetic waves that carry more energy per quanta and have the ability to break bonds between molecules, e.g. x-rays while non-ionising radiation are the fields whose quanta are insufficient to break molecular bonds. ${ }^{60}$ The telecommunication masts emit non-ionizing radiation. ${ }^{61}$ It has been established that minimal exposure to ionising radiation is dangerous to human health. ${ }^{62}$ However, researchers are still divided about the health risks of exposure to the non-ionising electromagnetic radiation emitted by the telecommunication masts. ${ }^{63}$

58 Gavin A, "Addressing a Community's Cancer Cluster Concerns" Ulster Med. Journal 75, no. 3 (2006): 195-199. Recently, some countries have also been reported to have banned installation of telecommunication masts in residential and educational areas. See Mihika B. and Sandeep, A. A., "State approves policy ban on installation near schools" The Indian Express, March 9, 2014 http://indianexpress.com/article/cities/mumbai/state-approves-policy-ban-on-

installation-near-schools/; BS Reporter, "Telecom towers banned near educational institutions", Business Standard, December 25, 2013, http://www.business-standard.com/article/economy-policy/telecom-towersbanned-near-educational-institutions-113122500769_1.html. World Health Organization, "Electromagnetic fields"

60 Ibid.

61 ICNIRP, "Guidelines for Limiting Exposure to Time-varying Electric, Magnetic and Electromagnetic Fields (up to $300 \mathrm{GHz}$ )" Health Physics 74, no. 4 (1998): 494-522.

62 Agbo and Nnadi, "Hazardous effects of EM Radiation from citing Mobile Phone masts close to Residential Houses and Schools", 455; Akintonwa, Busari, Awodele and Olayemi, "The Hazards of Non-Ionizing Radiation of Telecommunication Mast in an Urban Area of Lagos, Nigeria", 31-35; Santini, et al., "Investigations on the health of people living near mobile telephone relay stations", 369-373; Abdel-Rassoul, G, et al., "Neurobehavioral effects among inhabitants around mobile phone base stations", 434-40.

63 Stewart, et al., Mobile Phones and Health, 3; World Health Organization, "Electromagnetic fields". 
It has been argued by some scientists that the continuous (acute) exposure to the non-ionising radiation has adverse biological effects on humans. ${ }^{64}$ Non-ionising radiation emitted through radiofrequency and microwave transmissions has been found to trigger some thermal reaction in the human tissue thereby leading to burn or increased human body temperature, accumulation of electrical charge on the body surface and disturbance of nerve and muscle response. ${ }^{65}$ The International Agency for Research on Cancer has recently included brain cancer as one of the high potential dangers of acute exposure to the non-ionising radiation from radiofrequency and microwave electromagnetic fields. ${ }^{66}$ Although this study appears to be the only high profile scientific report on this issue, it has been adopted by some organisations including the United States Department of Labour. ${ }^{67}$

There are, however, contrary claims that exposure to non-ionizing radiation emitted by telecom installations has no significant health hazard on the residents. It has been argued in later studies that the evidence of health hazard is either contradictory or unproven. ${ }^{68}$ According to Swerdlow et al., available evidences have shown that adults are not likely to suffer from cancer within about 10-15 years of

64 IARC Working Group on the Evaluation of Carcinogenic Risks to Humans, Non-Ionizing Radiation, Part II: radiofrequency Electromagnetic Fields (Lyon: International Agency for Research on Cancer, 2011), 34. See also Baan, R., et al., "Carcinogenicity of radiofrequency electromagnetic fields" The Lancet Oncology 12, no. 7 (2011): 624-626.

65 Kwan-Hoong Ng, "Non-Ionizing Radiations - Sources, Biological Effects, Emissions and Exposures" (presentation, International Conference on NonIonizing Radiation at UNITEN ICNIR 2003 titled Electromagnetic Fields and Our Health, 20-22 October 2003), 4. See also Martin C.J. and Sutton D.G., Practical Radiation Protection in Health Care (Oxford: Oxford University Press, 2002), 3-11 and 369-391.

66 IARC Working Group, Non-Ionizing Radiation, Part II: radiofrequency Electromagnetic Fields, 34; Baan, "Carcinogenicity of radiofrequency electromagnetic fields", 624-626; World Health Organisation, "IARC classifies radiofrequency electromagnetic fields as possibly carcinogenic to humans", Press Release No. 208, May 31, 2011, accessed September 22, 2015,. http://www.iarc.fr/en/media-centre/pr/2011/pdfs/pr208_E.pdf

67 See United States Department of Labour, "Safety and Health Topics: NonIonizing Radiation", US Department of Labour, accessed September 22, 2015 https://www.osha.gov/SLTC/radiation_nonionizing/.

68 Independent Expert Group on Mobile Phones, Mobile Phones and Health (Oxford: National Radiological Protection Board, 2000), 40-102. 
exposure to RF radiation. ${ }^{69}$ Notwithstanding their opposing stance, these studies do not expressly disprove the claims that the telecommunication devices are potentially harmful to human health and neither did they discountenance the possibility of risks to human health. ${ }^{70}$ They only provide alternative views to the debate because of the unconvincing stance of the earlier studies that suggest the existence of adverse biological effect of telecommunication devices. In one of its conclusions to a study on mobile telecommunication and health, an independent expert group of scientists stated that:

There is evidence that RF fields can affect membrane proteins and can change the movement of ions across membranes. Some of these effects seem to occur in cells only at temperatures well below normal body temperature or with RF intensities that cause significant heating. However, some evidence suggests that RF radiation at levels produced by mobile phones might influence ion channels and other membrane proteins of neurons in the brain under normal conditions. This might cause subtle changes in cell function, but the significance of such effects for human health is uncertain. Moreover, these effects have not been independently confirmed, which is important given the frequent lack of reproducibility of RF biological effects. $^{71}$

It is therefore clear that the debate on the adverse effect of RF and electromagnetic radiation from telecommunication installations and devices is not settled yet. Thus, the common general conclusion from the experts is that there is need for further research on the possibility of non-ionizing radiation posing any health risk. $^{72}$

69 Swerdlow, A. J. et al., "Mobile Phones, Brain Tumours and the Interphone Study: Where Are We Now?" Environ Health Perspect. 119, no. 11 (2011): 1534-1538.

70 See Independent Expert Group on Mobile Phones, Mobile Phones and Health in Chapter 5.21, 5.26, 5.41

71 Independent Expert Group on Mobile Phones, Mobile Phones and Health, 4950 .

72 See generally: ICNIRP, "Health Issues Related to the use of Hand-Held Radiotelephones and Base Station Transmitters" Health Physics 70 (1996): 587593; Swerdlow, "Mobile Phones, Brain Tumours and the Interphone Study" 1534-1538; Independent Expert Group on Mobile Phones, Mobile Phones and Health; Kwan-Hoong Ng, Radiation, Mobile Phones, Base Stations and Your Health (Kuala Lumpur: Malaysian Communications and Multimedia Commission, 2003); Mann S.M., et al., Exposure to Radio Waves near Mobile Phone Base Stations (Oxon, UK: National Radiological Protection Board, 
It may, therefore, be argued that since telecommunication is relatively a recent development and any significant health hazard can only manifest over some relatively long period of time, one may need to take some precautionary measures to reduce exposure to radiation whether ionizing or non-ionizing, so that little or no damage would have been done by the time outcome of the research confirm the hazardous nature of non-ionizing radiation. As a result of the uncertainty of the scientific proof of the harmful effect of the installation of telecommunication masts and base stations around residential areas, the international communities have adopted a general approach known as the 'Precautionary Principle.'

\section{Precautionary Principle on Environmental Protection}

The concept of precautionary approach connotes the pragmatic steps expected to be taken by an organisation or state when an activity raises threats of harm to human health or the environment but the cause and effect relationships are yet to be scientifically proven. ${ }^{73}$ The approach, according to Stewart, is generally premised on the principle that regulation of harmful activities should not be overlooked because of lack or uncertainty in scientific evidence against the activity. ${ }^{74}$ In relation to the environment and public health, principle 15 of the Rio Declaration on Environment and Development $1992^{75}$ provides that:

2000), 33; Moulder J. E., "Frequently Asked Questions (FAQs) about Mobile Phone Base Antennas and Human Health", accessed October 2, 2003, http://www.mcw.edu/gcrc/cop/cell-phone-health-FAQ/toc.html.

73 Gollier, C., Bruno J. and Nicolas, T., "Scientific Progress and Irreversibility: An Economic Interpretation of the "Precautionary Principle"' Journal of Public Economics 75, no. 2 (2000): 229-253; Andrew, J. and O'Riordan, T., "The precautionary principle: a legal and policy history" in The precautionary principle: protecting public health, the environment and the future of our children, ed. Marco Martuzzi and Joel A. Tickner (World Health Organization, 2004); Science and Environmental Health Network, "Precautionary Principle: Wingspread Conference on the Precautionary Principle", Science and Environmental Health Network, accessed September 24, 2015, http://www.sehn.org/wing.html.

74 Stewart, R. B., "Environmental Regulatory Decision Making Under Uncertainty" Research in Law and Economics 20 (2002): 76.

75 Popularly described as Rio Declaration. The Rio Declaration was adopted by the United Nations General Assembly at the 1992 United Nations Conference on Environment and Development (UNCED) held at Rio de Janeiro from 3-14 June 1992. 
"In order to protect the environment, the precautionary approach shall be widely applied by States according to their capabilities. Where there are threats of serious or irreversible damage, lack of full scientific certainty shall be not used as a reason for postponing cost-effective measures to prevent environmental degradation.",76

This approach has since been adopted in many other international instruments on environment ${ }^{77}$ including the 1998 Wingspread Statement on the Precautionary Principle, ${ }^{78}$ the Commission of the European Communities' Communication from the Commission on the Precautionary Principle $2000,{ }^{79}$ and the Cartagena Protocol on Biosafety $2000^{80}$, Other international environmental treaties that have adopted this approach include United Nations Convention on Climate Change, the United Nations Fisheries Agreement for Straddling Stocks and Highly Migratory Fish Stocks, the London Convention on Ocean Dumping of Industrial and Radioactive Wastes and Ocean Incineration. ${ }^{81}$ The thrust of the principle is to engage states to commit their full resources towards developing policies and practices that protect the environment among others. ${ }^{82}$ Since the evolution of the concept of precautionary principle and due to the resistance to its

76 United Nations Environment Programme, Rio Declaration on Environment and Development 1992 (UNEP, 1992); Recuerda, M. A. "Dangerous interpretations of the precautionary principle and the foundational values of the European Union Food Law: Risk versus Risk" Journal of Food Law \& Policy 4, no. 1 (2008): 1-43.

77 Carl Smith, "The Precautionary Principle and Environmental Policy: Science, Uncertainty, and Sustainability" Int J Occup Environ Health 6, no. 3 (2000): 264; Gullett, W, "Environmental protection and the precautionary principle: a response to scientific uncertainty in environmental management", Environmental and Planning Law Journal 14, no. 1 (1997): t 55.

78 The 1998 Wingspread Statement on the Precautionary Principle was a resolution reached by independent lawyers, scientists, philosophers and environmental activists at a Conference convened by the Science \& Environmental Health Network on 26 January, 1998.

79 The EC Communication on Precautionary Principle was adopted on February 2, 2000 at Brussels. See European Commission, "Commission adopts Communication on Precautionary Principle", European Commission, accessed May 5, 2016, http://europa.eu/rapid/press-release_IP-00-96_en.htm.

80 The Cartagena Protocol on Biosafety to the United Nations Convention on Biological Diversity was adopted on the $29^{\text {th }}$ January, 2000 at Montreal.

81 Carl Smith, "The Precautionary Principle and Environmental Policy", 264.

82 Carolyn Raffensperger, "Precaution: Belief, Regulatory System, and Overarching Principle" Int J Occup Environ Health6, (2000):266-269. 
use at some quarters, ${ }^{83}$ the precautionary approach has been used in two different forms by countries. There are thus the 'strong' and 'weak' precautionary approaches. ${ }^{84}$ The strong precaution prescribes that once there is a potential threat of harm to the environment or human as a result of a particular activity; the state must make a law prohibiting such an activity expressly. ${ }^{85}$ On the other hand, the weak precaution only requires the state to stop the harmful activity if the harm from such activity would otherwise be serious and irreversible. ${ }^{86}$ Many countries have, however, chosen the weak precaution because it is considered to be in conformity with human natural inclination and to balance between the risk involved and the developmental goals aimed at. ${ }^{87}$ Basically, the principle departs from the understanding of environment as a utilitarian commodity and enunciates the protection of the environment as a 'moral right' ${ }^{88}$ Meanwhile, beyond theoretical dispositions, the practical application of the precautionary principle presupposes the following: ${ }^{89}$

83 There are various criticisms levelled against the use of the precautionary principle in protecting the environment. Some of the criticisms include that the application of the precautionary principle would impair innovation and developmental progress especially in the developing nations; that in many cases, the precautionary principle is vague in its proscription of harmful elements. See generally, David Deutsch, The Beginning of Infinity(UK: Penguin Books , 2011); Jimenez-Arias, Luis G. Biothics and the Environment (Libros en Red., 2008),. 73; van den Belt, H., "Debating the Precautionary Principle: "Guilty until Proven Innocent" or "Innocent until Proven Guilty"?". Plant

1122

6. doi:10.1104/pp.103.023531.PMC 526264. PMID 12857792; Merchant, G., et al., "Impact of the Precautionary Principle on Feeding Current and Future Generations" CAST Issue Paper 52, (2013).

84 New Zealand Treasury Department, "Precautionary Principle: Origins, definitions, and interpretations." Treasury Publication, Government of New Zealand, $\quad$ accessed May 5, 2016,http://www.treasury.govt.nz/publications/research-policy/ppp/2006/0606/05.htm.

Sachs, Noah M., "Rescuing the Strong Precautionary Principle from its Critics" University of Illinois Law Review 4, (2011): 1295-1296;

Mandel, Gregory N.; Gathii, James Thuo"Cost Benefit Analysis Versus the Precautionary Principle: Beyond Cass Sunstein's Laws of Fear" University of Illinois Law Review 5, (2006): 1037-1079.

87 Cass R. Sunstein, "The paralyzing principle: Does the precautionary principle point us in any helpful direction?" Regulation (2002-2003): 32-37.

88 Gullett, W., "Environmental protection and the precautionary principle", 54.

89 See Claudia Saladin, "Precautionary Principle in International Law" Int J Occup Environ Health6, (2000): 270. 
i. that precautionary measures must be taken even if not all cause and-effect relationships are fully understood;

ii. that the proponent of a potentially harmful activity must bear the burden of proving the safety of his activity;

iii. that environmental and public health decisions must be made in an open, informed, and democratic manner;

iv. that all the full range of alternatives to the potentially harmful activity must first be examined; and

v. that the states must rely on the 'weight-of-theevidence' approach, rather than waiting for absolute scientific certainty.

In view of the Rio Declaration and the other related international instruments, some countries like United Kingdom as well as international organisations like World Health Organisation and World Bank have commissioned expert scientists to empirically study and formulate guidelines to prescribe the limits at which exposure to RF and electromagnetic radiation would be actually harmful to humans and the environment. Some important guidelines formulated include the International Commission on Non-Ionizing Radiation Protection (ICNIRP) Guidelines, the World Health Organisation guidelines and International Financial Corporation guidelines.

\section{International Commission on Non-Ionizing Radiation Protection (ICNIRP) Guidelines}

The ICNIRP is the regulatory body for non-ionizing radiation. ${ }^{90}$ It consists of independent scientists whose function is to assess the effect of non-ionising radiation on humans and to provide guidelines on how to limit and protect human exposures. ${ }^{91}$ In 1998, the ICNIRP

90 ICNIRP, "General approach to protection against non-ionizing radiation" Health Physics 82, no. 4 (2002): 540-548; ICNIRP, "Guidelines for Limiting Exposure to Time-varying Electric, Magnetic and Electromagnetic Fields (up to 300 GHz)" Health Physics 74, no. 4 (1998): 494-522.

91 ICNIRP, "General approach to protection", 540; ICNIRP, "Guidelines for Limiting Exposure", 494. 
produced a guideline that prescribes the minimum level of electromagnetic radiation safe for human exposure..$^{92}$ The guidelines, however, considered only established short term immediate health effects of such exposure because long term effects such as cancer or reproductive anomaly are yet to be established due to insufficient or inconsistent data. ${ }^{93}$ The guidelines, therefore, set the limit of exposure of electromagnetic radiation from telecommunication masts not to be above 300 gigahertz, in order to ensure the safety of humans. ${ }^{94}$ The basis for this limitation is because if the limit is not set, and researchers eventually discover a cogent adverse biological effect of the radiations emitted from the masts and its base stations, the remedy might be more complex and costlier. ${ }^{95}$ Demonstrating its precautionary approach to exposure hazard from non-ionising radiation devices, the ICNIRP noted that "the industries causing exposure to electric and magnetic fields are responsible for ensuring compliance with all aspects of the guidelines". ${ }^{96}$ This is in consonance with one of the four core components of the principle of precautionary approach which shifts the burden of showing and assuring that an activity is not potentially harmful to humans or the proponent of that activity. ${ }^{97}$ This suggests, therefore, that even though

92 ICNIRP, "Guidelines for Limiting Exposure”, 494.

93 ICNIRP, Ibid, 496. See also Tenforde, T. S., "Interaction of ELF magnetic fields with living systems", in Biological Effects of Electromagnetic Fields, ed. Polk, C. and Postow, E. (Boca Raton, FL: CRC Press, 1996), 185-230; National Academy of Science, Possible Health Effects of Exposure to Residential Electric and Magnetic Fields (Washington, DC: National Academy Press, 1996); National Radiological Protection Board, "Electromagnetic fields and the risk of cancer: Supplementary report by the Advisory Group on Non-ionising Radiation of 12 April 1994" Radiol. Prot. Bull. 154, (1994): 10-12; Shaw, G. W. and Croen, L. A., "Human adverse reproductive outcomes and electromagnetic fields exposures: review of epidemiologic studies" Environ. Health Persp. 101 (1993): 107- 119; Bergqvist, U., "Pregnancy outcome and VDU work-a review", in Work with Display Units '92-Selected Proceedings of the 3rd International Conference WWDO '92, Berlin Germany, 1-4 September 1992, ed. Luczak, H., Cakir, A. \& Cakir, G. (Amsterdam: Elsevier, 1993), 70-76. ICNIRP, "Guidelines for Limiting Exposure" 508-509.

95 ICNIRP, "General approach to protection" 546-547.

96 ICNIRP, "Guidelines for Limiting Exposure", 514.

97 See Kriebel, D. et al., "The Precautionary Principle in Environmental Science" Environmental Health Perspectives 109, no. 9 (2001): 871; Cooper, K. et al., Environmental Standard Setting and Children's Health (Ontario: Canadian Environmental Law Association \& Ontario College of Family Physicians, 2000), 158; McClenaghan, T. et al., "Environmental Standard Setting and Children's 
the ICNIRP does not explicitly discourage the installation of telecommunication equipment around residential areas, the body obliges both the industry and the state to ensure that precautionary measures are taken to adequately prevent the outbreak of hazards to the public.

\section{World Health Organisation (WHO) Guidelines}

The World Health Organization stated in 2010 that current evidence of scientific research does not confirm the existence of any health consequences from exposure to low levels of electromagnetic fields, that is, below 300 gigahertz, based on the current level of knowledge. ${ }^{98}$ It accepted that gaps in knowledge currently exist about long term exposure to various levels of electromagnetic radiation and that further research is needed. ${ }^{99}$

But in the meantime, WHO has issued a series of recommendations, based on the precautionary approach, including strict adherence to existing international safety standards and guidelines; simple protective measures such as barriers around strong electromagnetic field sources, and consultations with local authorities and the public in choosing the site of new mobile phone base stations. ${ }^{100}$ The WHO in formulating its recommendations adopted the Precautionary Approach suggested by both the Independent Expert Group on Mobile Phones and the ICNIRP guidelines. ${ }^{101}$

\section{International Finance Corporation (IFC) Guidelines}

The IFC, a subsidiary of the World Bank, also designed a guideline as a technical reference document to ensure that companies involved in the World Bank's projects apply the precautionary approach. The guideline is therefore formulated specifically to develop a Good

Health in Canada: Injecting Precaution into Risk Assessment" Journal of Environmental Law and Practice 12, no. 2 (2003): 141-279.

98 World Health Organization, "Electromagnetic Fields".

99 Ibid.

100 Ibid.

101 World Health Organization, 'Electromagnetic fields', World Health Organisation, accessed August 19, 2010, http://www.who.int/peh-emf/en; Stewart et al, Mobile Phone and Health, 107. 
International Industry Practice (GIIP) ${ }^{102}$ for the World Bank technical, engineering and telecommunication contractors. ${ }^{103}$ The guideline also acknowledges the hazardous nature of telecommunication devices and installations but also reiterate the lack of sufficient scientific evidence to substantiate the concern. ${ }^{104}$ The guideline nevertheless advocates for the precautionary approach by noting that "while the evidence of adverse health risks is weak, it is still sufficient to warrant limited concern." 105 This statement aligns with the core principle of the precautionary approach that harmful industrial activities should not be left unregulated due to lack or uncertainty in scientific evidence. ${ }^{106}$ Although the IFC guideline on Telecommunication recognises the territorial differences and biological tolerance, it nevertheless made some general precautionary recommendations. To prevent public exposure to hazardous materials, the guideline recommends that the companies should ensure that new equipment is free from hazardous chemicals and substances while the old ones should be carefully managed and gradually phased out. ${ }^{107}$ They should also consider implementing take-back programmes whereby used devices could be returned to the manufacturers for proper recycling and preventing the disposal of e-wastes. ${ }^{108}$ Furthermore, to prevent exposure to EMF radiation, the guideline recommends that average and peak exposure limits should remain below the ICNIRP guidelines; public access to

102 GIIP has been defined as the exercise of professional skill, diligence, prudence and foresight that would be reasonably expected from skilled and experienced professionals engaged in the same type of undertaking under the same or similar circumstances globally. See International Finance Corporation, "Environmental, Health, and Safety Guidelines for Telecommunications-Industry Sector Guidelines, April 30, 2007, accessed September 26, 2015, http://www.ifc.org/wps/wcm/connect/0985310048855454b254f26a6515bb18/Fi nal\%2B-\%2BTelecommunications.pdf?MOD=AJPERES\&id=1323152343828. ibid.

Ibid.

105 International Finance Corporation, Ibid. See also US National Institute of Environmental Health Sciences (NIEHS) and National Institutes of Health (NIH), "EMF Questions and Answers: Electric and Magnetic Fields Associated with Use of Electric Power", National Institute of Environmental Health Sciences and National Institutes of Health, accessed September 26, 2015, http://www.niehs.nih.gov/emfrapid/booklet/emf2002.pdf.

106 Stewart, R. B., "Environmental Regulatory Decision Making Under Uncertainty", 76.

107 International Finance Corporation, "Environmental, Health, and Safety Guidelines for Telecommunications", 4. 
telecommunication antennas should be limited while the public welfare should be given adequate consideration by consulting the local communities during the installation of the equipment in order to know their perception about EMF radiation. ${ }^{109}$ And regarding emission of air and noise pollutants, the guideline recommends that both the state and the companies should avoid using fuelled power generators as a permanent source of electricity as well as using noise suppression shields or locating the generators far away from houses. ${ }^{110}$

However, as a general precautionary measure, the guideline directs that the companies should always refer to the IFC General Guideline. ${ }^{111}$ Meanwhile, where the contents of the guidelines differ from the regulation of the host country where a World Bank project is being executed, the Telecommunication guideline directs that the contractor should implement the more stringent of the two although the contractors may sometimes employ their professional expertise to apply an approach lesser than the directives in the guidelines. ${ }^{112}$ However, where the lesser stringent approach is used; the company must give a detailed justification showing that the choice is protective of human health and the environment. ${ }^{113}$

\section{LEGAL RESPONSES TO ADVERSE IMPACTS OF TELECOMMUNICATION INSTALLATIONS IN RESIDENTIAL AREAS IN NIGERIA}

The Constitution of Federal Republic of Nigeria ${ }^{114}$ vests the National Assembly with power to make laws on any matter on exclusive legislative lists to the exclusion of the States. Telecommunications is covered under items 46,66 and 68 of part 1 in the $2^{\text {nd }}$ schedule of the

109 Ibid., 5.

110 Ibid., 5 .

111 For the general guidelines, see International Finance Corporation, "Environmental, Health, and Safety General Guidelines", International Finance Corporation, accessed September 2015, http://www.ifc.org/wps/wcm/connect/554e8d80488658e4b76af76a6515bb18/Fi nal\%2B-\%2BGeneral\%2BEHS\%2BGuidelines.pdf?MOD=AJPERES. Ibid.

113 Ibid

114 See Sections 4(2) and (3) of the Constitution of the Federal Republic of Nigeria, 1999. 
exclusive lists of the Constitution. In exercise of this power, the National Assembly passed some laws that have relevance with the protection of environment particularly the habitants, against telecommunications installations hazards.

\section{Nigerian Communications Act, 2003}

The primary regulation or instrument in the telecommunications industry in Nigeria is the Nigerian Communications Act, 2003. The Act establishes ${ }^{115}$ the Nigerian Communications Commission (NCC) as a primary regulatory body of the telecommunications sector in the country with various oversight functions which include making regulations and guidelines ${ }^{116}$ for effective running of telecommunication industries in the country. The Nigerian Communications Act creates and provides a regulatory framework for the Nigerian communications industry. The Act detailed an elaborate and comprehensive administrative and regulatory framework for the development, growth and sustenance of the telecommunication industry in Nigeria. This includes the protection of environment in the course of constructing telecommunications installations.

The Act also gives the Commission power to prescribe and enforce technical specifications and standards for the importation and use of communications equipment in Nigeria and for connecting or interconnecting communications equipment and systems. ${ }^{117}$ The Commission is also expected to carry out approval tests on communications equipment and to issue certificates on the basis of technical specifications and standards prescribed from time to time. ${ }^{118}$ The law seeks to protect against the negative impact of telecommunication installations by directing the telecommunication licensees to "take all reasonable steps to ensure that the facilities cause as little detriment and inconvenience as possible to the public. ${ }^{119}$ The law also mandates the network operators to restore the

\footnotetext{
115 See Section 3 (1) of Nigerian Communications Act, 2003, Cap N97, Laws of the Federation of Nigeria, 2004.

116 See Section 4(1) (i) of the Nigerian Communications Act, 2003, which empowers the Commission to make and enforce of such regulations as may be necessary under the Act to give full force and effect to the provisions of the Act, See also Section 70 of the Act.

117 Section 4(1) (1) of Nigerian Communications Act, 2003.

118 Section 4 (1) (n) of Nigerian Communications Act, 2003.

119 Section 136 (1) of Nigerian Communications Act, 2003.
} 
lands upon which they installed their base stations and masts back to condition similar to the condition of the lands before the installation. ${ }^{120}$ The licensees are further admonished while installing the telecommunication equipment to take reasonable steps to act in accordance with good engineering practice; protect the safety of persons and properties, and protect the environment. ${ }^{121}$

The above provisions are inserted to ensure that the telecommunication operators in Nigeria conform to the internationally recognised principle of precautionary approach. However, even though the efficacy of the provisions of the Act might not have been adequately tested through the Nigerian courts, ${ }^{122}$ it appears the Act has some lacunas that could impair the effectiveness of the law. For instance, the Act only encourages the licensees to cause as little detriment or inconvenience as is practicable to the land, it does not specify the level of damage that could be considered little. This implies that the operators are given the discretion to determine what they consider as little damage to the environment. Similarly, the Act does not stipulate how to measure the littleness of the damage. Furthermore, there is no evidence that the Commission also conducts on-site assessment to ascertain how the operators have restored the land back to its earlier condition. If such assessment was conducted, the structural collapse of the septic tank in Figure 3 would have been detected and averted earlier.

\section{Guidelines on Technical Specifications for the Installations of Masts and Towers, 2009}

In exercising its power under the Act to make regulations and guidelines, the Nigeria Communication Commission (NCC) issued Guidelines on Technical Specifications for the Installations of Masts and Towers in April 2009. The guidelines provide for measures to prevent environmental challenges in the course of constructing masts and towers. The objectives of the guidelines particularly, in respect of siting telecommunications towers and masts include minimizing their

\footnotetext{
120 Section 136 (2) of Nigerian Communications Act, 2003.

121 Section 136 (3) of Nigerian Communications Act, 2003.

122 The only case found in the course of this research where the installation of telecommunication infrastructure became a source of dispute is the case of Engr. Charles Jimoh $v$ Globacom Limited \& Anor, Suit No. KWS/OM/21/2014. The suit is still ongoing and not concluded yet.
} 
number, protecting and promoting public safety, and mitigating the adverse visual impacts on the community whilst promoting the provision of telecommunications service to the public. ${ }^{123}$

The Guidelines stipulate the standards to be adhered to by telecommunications services providers and operators towards ensuring environmental safety and sound engineering practices. ${ }^{124}$ The guidelines require the engineers to take cognizance of types and constituents of tower structures and use data on wind speed in Nigeria as reference materials in the design of masts and towers. ${ }^{125}$ The guidelines also require the telecommunications operators to take cognizance of the provisions of the Nigerian Communications Act in the siting of telecommunications masts and towers and to be guided by the provisions of the Guidelines on Collocation and Infrastructure Sharing ${ }^{126}$ issued by the Commission. ${ }^{127}$

To conform to the principle of precautionary approach, the guidelines encourage the operators to use stealth or camouflage designed masts in order to mitigate adverse visual impacts of towers and antennas structure on the community. ${ }^{128}$ The guidelines also direct the operators to conform to the standards on radio frequency in order to minimise public exposure to EMF radiation, heat, smoke and noise pollution. ${ }^{129}$ Furthermore, the Act stipulates that telecommunication towers installed within residential areas should not be taller than 25 meters except it is approved by the Commission having being satisfied that the increased height of the tower will not be detrimental to public health, safety or general welfare; will not

123 See Chapter One, Section 3(1) of Guidelines on Technical Specifications for the Installation of Telecommunications Masts and Towers issued on $9^{\text {th }}$ April, 2009. Chapter One, Section 1 (1) of Guidelines on Technical Specifications for the Installation of Telecommunications Masts and Towers 2009. Chapter One, Section 1(2) of Guidelines on Technical Specifications for the Installation of Telecommunications Masts and Towers 2009.

Collocation and Infrastructural sharing is one of the ways by which the environment is protected from the adverse impacts of telecommunications installations. In the operators' desire to ensure quality of service to all their subscribers and subsequent rollout of towers and masts, there is bound to be proliferation of masts and towers in a particular vicinity. Chapter One, Section 3 (1) of Guidelines on Technical Specifications for the Installations of Towers and Masts, 2009.

128 Chapter One, Section 3 (1) of Guidelines on Technical Specifications for the Installation of Telecommunications Masts and Towers 2009.

129 Chapter One, Section 3 (2) and (3) of Guidelines on Technical Specifications for the Installation of Telecommunications Masts and Towers 2009. 
have negative effect on the neighbourhood; is in conformity with the plan of the particular area and the general plan of the community and will not impair compliance with any other applicable laws or guidelines. ${ }^{130}$ And it should not be less than 5 meters away from the nearest demised property. ${ }^{131}$ To avoid avian collision as well as aircraft mishap, the guidelines provide that the towers and masts must be painted and lightened. ${ }^{132}$ Similarly, the guidelines require that the operators should provide earthling and lightning protectors so as to avoid excessive voltage discharge. ${ }^{133}$ To ensure compliance, the guidelines stipulate that any erring operator would be sanctioned by ordering the removal of the offending mast or tower at the expense of the owner. ${ }^{134}$

Compliance with these guidelines, however, also seem to be lax as some provisions are found to be flouted but without any apparent sanction. For instance, it is found that some antennas are located less than the 5 meters stipulated and have not been removed. ${ }^{135}$ Likewise, many towers and masts that are taller than houses are neither lighted at night nor does it appear that they were provided with a lightning protector as the collapse in Figure 4 shows.

\section{National Environmental Standard and Regulations Enforcement Agency (Establishment) Act, 2007 (NESREA Act)}

The Act establishes ${ }^{136}$ the National Environmental Standards and Regulations Enforcement Agency (NESREA) as Nigeria's primary

130 Chapter Five, Section 1 (b) of Guidelines on Technical Specifications for the Installation of Telecommunications Masts and Towers 2009.

131 Ibid

132 Chapter Two, Section 4 (3) and (4), See also Chapter Five Section 9 (12) (a) of Guidelines on Technical Specifications for the Installation of Telecommunications Masts and Towers 2009.

133 Chapter Two, Section 5 (1) of Guidelines on Technical Specifications for the Installation of Telecommunications Masts and Towers 2009.

134 Chapter One, Section 3 (6) of Guidelines on Technical Specifications for the Installation of Telecommunications Masts and Towers 2009.

135 Mrs. H. A. (housewife who lives in a house near which a telecom base station has been installed), Interview by Imam-Tamim, Muhammad Kamaldeen, Ilorin, Kwara State, Nigeria, January 12, 2015.

136 Section 1 (1) of National Environmental Standards and Regulations Enforcement Agency (Establishment) Act, 2007. 
environmental protection agency. ${ }^{137}$ The Act empowers NESREA to enforce compliance with laws, guidelines, policies and standards on environmental matters; enforce compliance with the provisions of international agreements, protocols, conventions and treaties on the environmental pollution. ${ }^{138}$

To prevent environmental hazards like air, noise and water pollution, land degradation or discharge of hazardous waste, which may result from any private or industrial activities which include telecommunications industries, the Act empowers the Agency to make regulations setting specifications and standards for the protection and enhancement of the quality of Nigeria's environmental resources, so as to promote the public health or welfare and the natural development and productive capacity of the nation's habitat. ${ }^{139}$ Non-compliance or violation of these provisions by individual or cooperate bodies attracts penalty of a fine or a term of imprisonment or both. ${ }^{140}$

In order to provide for effective enforcement of environmental standards, regulations, rules, laws, policies and guidelines by the newly established NESREA, the Minister of Environment, Urban and Regional Development is empowered to make regulations for the general purposes of carrying out or giving full effect to the functions of the Agency under the NESREA Act. ${ }^{141}$ In exercise of this power, the Minister has made several Regulations including National Environmental (Standards for Telecommunications and Broadcasting Facilities) Regulations, 2011 and National Environmental (Food, Beverages and Tobacco Sector) Regulations, 2009.

In a bid to curb air and noise pollutions mostly generated by the power generating set which supplies backup electricity to the Base

137 Section 1 (2) (a) of National Environmental Standards and Regulations Enforcement Agency (Establishment) Act, 2007.

138 Section 7 of National Environmental Standards and Regulations Enforcement Agency (Establishment) Act, 2007.

139 See sections 20, 21, 22, 23, 25, 26 and 27 of National Environmental Standards and Regulations Enforcement Agency (Establishment) Act, 2007 on air pollution, ozone depletion, noise pollution, water resources protection, environmental sanitation, land resource protection and hazardous waste prevention respectively.

140 Sections 20 (3 \&4), 21 (3), 22 (3 \&4), 23 (3\&4), 26 (3\&4) and 27 (2\& 3 ) of National Environmental Standards and Regulations Enforcement Agency (Establishment) Act, 2007.

141 Section 34 (c) of National Environmental Standards and Regulations Enforcement Agency (Establishment) Act, 2007. 
Station, NESREA in its 2009 Regulations ${ }^{142}$ directs that any company including network operators with any source or potential source of air and noise pollutions should take measure and develop plan to prevent and control such pollutions. These NESREA Regulations particularly, National Environmental (Standards for Telecommunications and Broadcasting Facilities) Regulations, 2011 have generated controversies in the regulation of telecommunications installation as they affect the environment. One of such controversies is in the area of set-back of towers and mast to the residential building. In the NCC's Regulations, the minimum set-back of telecommunications towers to residential building is 5 metre $^{143}$ while the NESREA Regulations provide for minimum of 10 metre. ${ }^{144}$ Apart from the fact that the dichotomy in these Regulations generated regulatory clashes between the NCC and NESREA ${ }^{145}$ it also gives room for excuses for non-compliance on the part of operators. ${ }^{146}$

\section{Environmental Impact Assessment (EIA) Act, 1992}

The EIA is generally used to ensure that potential environmental hazards on public health and property are forecasted and mitigating

142 Sections 20 and 22, National Environmental (Food, Beverages and Tobacco Sector) Regulations, 2009.

143 Chapter Five, Section 9 (9) (c) (i), Guidelines on Technical Specifications for the Installation of Telecommunications Masts and Towers.

144 National Environmental (Standards for Telecommunications/Broadcasting Facilities) Regulations, 2010, S. I. No. 11.

145 Obi, P., "When NCC, NESREA Flex Muscles over Regulatory Issues", This Day Live, May 3, 2012 http://www.thisdaylive.com/articles/when-ncc-nesreaflex-muscles-over-regulatory-issues/115007/; ; Osuagwu, P. and Akinboade, L., "NCC, NESREA fight over MTN base station", Vanguard Newspaper, April 25, 2012 http://www.vanguardngr.com/2012/04/ncc-nesrea-fight-over-mtn-basestation/; Adekoya, A., "Between NCC and NESREA", Vanguard Newspaper, June 6, 2012, http://www.vanguardngr.com/2012/06/between-ncc-and-nesrea/. Ezekiel, E., "NESREA vs. NCC: Raging battle over regulation of telecoms masts", Nigerian Best Forum, July 31, 2012, accessed October 17, 2015, http://www.nigerianbestforum.com/generaltopics/nesrea-vs-ncc-raging-battleover-regulation-of-telecoms-masts/.

146 See Imasogie, T., "Understanding the NCC, NESREA face-off", People's Daily, accessed October 17, 2015, http://peoplesdailyng.com/weekend/index.php/opinion/opinion/1372understanding-the-ncc-nesrea-face-off. 
steps taken during the design stage of a project. ${ }^{147}$ Following this principle, the Nigerian EIA Act 1992 directs that before any person ${ }^{148}$ undertakes any project, they must first empirically consider any matter that "may likely or to a significant extent affect the environment or have an environmental effect on those activities..."149 The Act further empowers the NESREA to make regulations for the effective implementation of its provisions. However, the Act does not in practice implement the principle of precautionary approach. It only targets projects that may cause serious and significant adverse environmental effect. ${ }^{150}$ The Act specifically empowers the NESREA to exclude projects whose "environmental effects are likely to be negligible" from being assessed for their potential hazardous effect. Meanwhile, the principle of precautionary approach focuses on the latter types of project. ${ }^{151}$ Moreover, the exclusion is not justifiable as Nigeria lacks standard analytical laboratories that might produce ground breaking scientific findings to determine the severity of such negligible environmental hazard. ${ }^{152}$ Furthermore, the sanction prescribed is very negligible and

147 Nwoko, C. O., "Evaluation of Environmental Impact Assessment System in Nigeria" Greener Journal of Environmental Management and Public Safety 2, no. 1 (2013): 22-31.

Note that person is used here within the context of the jurisprudential 'legal person', which includes both natural and corporate legal persons. See Environmental Impact Assessment Act 1992, sections 1, 2 and 3. See Environmental Impact Assessment Act 1992, sections 1, 2, 3, 5 and 16.

See generally Stewart, "Environmental Regulatory Decision Making Under Uncertainty", 76; Gollier, Bruno \& Nicolas, "Scientific Progress and Irreversibility", 229-253. See also Science and Environmental Health Network, "Precautionary Principle: Wingspread Conference on the Precautionary Principle" where it has been argued that the minimal potential of the hazardous effect of a project on the environment and the public as well as the uncertainty or lack of scientific proof of harm should not absolve any person proposing the project from taking precautionary approach.

152 See "Reliable, High-Quality Clinical Laboratories Continue to Be in Short Supply in Nigeria Despite Efforts to Upgrade Accreditation and Professionalism", Dark Daily, accessed October 2, 2015, http://www.darkdaily.com/reliable-high-quality-clinical-laboratories-continueto-be-in-short-supply-in-nigeria-despite-efforts-to-upgrade-accreditation-andprofessionalism-807.; Ajayi, I. and Akingboye, O., "Lack of testing laboratory, bane of Nigeria's agric products, says Aganga", The Guardian Newspaper, April 24, 2015, http://www.ngrguardiannews.com/2015/04/lack-of-testing-laboratorybane-of-nigerias-agric-products-says-aganga/; Osagie, C., "EU Blames Lack of Laboratories for Fake Goods Influx", This Day Live, October 9, 2012, http://www.thisdaylive.com/articles/eu-blames-lack-of-laboratories-for-fake- 
could encourage the telecommunication companies to disregard the Act. The Act prescribes a fine of one hundred thousand naira or five years imprisonment for individual offenders while corporate offenders would only be fined between fifty thousand naira (equivalent to around 250.77 USD) ${ }^{153}$ and one hundred thousand naira (equivalent to around 501.54 dollars) ${ }^{154}$. The telecommunications companies are among the most profitable in Nigeria with a turnover of $\$ 9.8 \mathrm{~b}$ in $2014 .{ }^{155}$ Therefore, the sanction is a mere slap on the wrist. The Act can also be said to discountenance the precautionary approach because it does not give priority to public concern considerations where potentially hazardous projects are approved. ${ }^{156}$ According to section 11 of the Act, where a company believes that a project is potentially hazardous to the public and environment, it only

goods-influx/127183/; Adeyemi, T. O., "Science Laboratories and the Quality of Output from Secondary Schools in Ondo State, Nigeria" Asian Journal of Information Management 2, (2008): 23-30 where lack of standard libraries have been blamed for different public health related problems in Nigeria. See also Ladan, M. T. "Review of NESREA Act 2007 and Regulations 2009-2011: A New Dawn in Environmental Compliance and Enforcement in Nigeria" Law, Environment and Development Journal 8 (2012):, no. 1122.

153 The conversion rate was as at October $2^{\text {nd }}, 2015$ at about 11:38 am. See <http://themoneyconverter.com/USD/NGN.aspx>.

154 The conversion rate was as at October $2^{\text {nd }}, 2015$ at about 11:45 am. See $<$ http://themoneyconverter.com/USD/NGN.aspx >.

155 See Adepetun, A. "Nigeria's telecoms industry generates $\$ 9.8 \mathrm{~b}$ in 2014", The Guardian Newspaper, April 2015, http://www.ngrguardiannews.com/2015/04/nigerias-telecoms-industrygenerates-9-8b-in-2014/; Amzat, A., "Nigerian Telecoms Firms Frustrate Subscribers", accessed October 2, 2015, https://iwpr.net/global-voices/nigeriantelecoms-firms-frustrate-subscribers; Telecom Advisory Services Limited, "Nigerian telecom Sector: 10 Reasons why Nigeria will give you best returns", accessed October 2, 2015, https://www.enterpriseireland.com/EI_Corporate/en/Export-Assistance/International-Office-NetworkServices-and-Contacts/Telecoms-and-ICT-Seminar-Telecoms-AdvisoryServices-Nigeria.pdf. As at March 2015, the telecom industry was reported to have contributed $8.5 \%$ of the Nigerian GDP for the year. See "Industry Overview: \% Percentage Contribution of Telecoms Industry to GDP (2010 Mar' 2015)", Nigerian Communications Commission, accessed October 2, 2015, http://www.ncc.gov.ng/index.php?option=com_content\&view=article\&id=68:in dustry-overview \&catid=65: industry-information \&Itemid $=70$.

156 See Echefu, N. and Akpofure, E., "Environmental impact assessment in Nigeria: regulatory background and procedural framework" in UNEP EIA Training Resource Manual: Law, Policy and Institutional Arrangement, 72, accessed October 3 , 2015 , http://www.unep.ch/etu/publications/14)\%2063\%20to\%2074.pdf. 
needs to notify the government alone. There is no provision requiring the community where the project will be conducted to be consulted and alerted of the potential danger. ${ }^{157}$ This probably informs why the telecommunication companies arbitrarily proliferate base stations and antennas in residential areas. Notwithstanding the above, a major lacuna found in the EIA Act is that it does not appear to have even considered the potentially hazardous nature of the telecommunication installations as telecommunication projects are not included among those for which EIA is mandatory. ${ }^{158}$ These lacunas have contributed to the violation of the Act by both the government officials and the industry operators as it has been reported that most projects including telecommunication projects are executed without any environmental impact assessment. ${ }^{159}$

\section{CONCLUSION AND RECOMMENDATIONS}

There is no doubt that for the service providers to be able to provide quality of service in the telecom industries, there is need for urgent and continuous expansion of the telecom installations. However, the yearning for quality of service by subscribers, the inevitability of more installations by network providers to meet these yearnings and the concern for the adverse environmental consequences of more telecom installations create a kind of dilemma for the regulators, the telecommunication companies, scientists and the public. In order to balance these concerns, the international communities have resorted to applying the principle of precautionary approach especially since there is yet to be a consensus and ascertained scientific proof of the severe bio-hazardous effect of the EMF radiation emitted from the telecommunication masts and antennas. Therefore, scientific studies

157 Note that section 24 states that a mandatory study report should be published for public notice, however, the nature of the report would be too technical for the non-technically oriented residents to understand. Moreover, the law does not state the mode of the publication. See also Nwoko, "Evaluation of Environmental Impact Assessment System in Nigeria", 26 and 28. See Environmental Impact Assessment Act, sections 12 and 14.

159 Comfort Asokoro Ogaji, "The rational for the adoption of the EIA as a policy in Environmental Management in Nigeria", Comfort Asokoro Ogaji (blog), September 19, $2011 \quad(11: 28 \quad$ am), https://comfortasokoroogaji.wordpress.com/2011/09/19/the-rational-for-theadoption-of-the-eia-as-a-policy-in-environmental-management-in-nigeria/. 
by ICNIRP, IFC and WHO have identified minimum exposure reference levels as a precautionary measure to avoid any potential epidemic as a result of severe exposure to the EMF radiation.

Like other countries, Nigeria also has legislation regulating the use of the environment. In respect of the telecommunication industry, the relevant statutes include the NCC Act, the NESREA Act and EIA Act. These statutes especially the NCC Act and the NESREA Act have established two independent regulatory bodies to monitor the industry. Each of these Acts also gives directions on how the environment should be minded by the telecom operators particularly regarding the installation of masts and antennas. A cursory look at those statutes shows that they purport to align with the principle of precautionary approach to the protection of the environment and public health. However, a careful analysis reveals that the laws have some lacunas that depart from the precautionary approach and give the operators opportunity to disregard their responsibility towards the environment and public health.

However, unlike many other countries, there is a dearth of litigation on the enforcement and protection of environmental rights in general and challenging the installation of masts closely to residential apartments in particular. Two reasons could be advanced for this attitude. The first reason could be attributed to poverty and lack of environmental rights education among the populace. Despite the concerns being raised against installing telecommunication masts close to residential apartments, many property owners are found to deliberately invite the telecoms companies to install masts and base stations in their compound. Most of these property owners are found to be lack awareness about the possible hazard of exposure to EMF radiation and hazardous elements. ${ }^{160}$ The second reason is the high cost and length of time of prosecuting environmental cases in the Nigerian courts. The nature of environmental cases requires the

160 Ladan, M. T., “Access To Environmental Justice In Oil Pollution And Gas Flaring Cases As A Human Right Issue In Nigeria" (Presentation, Training Workshop for Federal Ministry of Justice Lawyers organized by the Institute for Oil and Gas Law, Abuja, November 28-30, 2011); Ogbodo, S. G., "The Role Of The Nigerian Judiciary In The Environmental Protection Against Oil Pollution: Is It Active Enough?", Nigerian Law Guru, accessed May 4, 2016, http://www.nigerianlawguru.com/articles/environmental\%20law/THE\%20ROL E\%20OF\% 20THE\%20NIGERIAN\%20JUDICIARY\%20IN\%20THE\%20ENVI RONMENTAL\%20PROTECTION\%20AGAINST\%20OIL\%20POLLUTION, $\% 20 I S \% 20 I T \% 20$ ACTIVE\%20ENOUGH.pdf. 
engagement of many experts at different stages from assessment of the possibility or the level of harm to filing the case in court (which needs the service of good lawyers) and proving the case through expert evidence. Thus, even the few Nigerians that are aware of their environmental rights and the likely harm that installation of telecommunication masts and base stations close to their homes could cause do not possess the financial strength to prosecute the matter. ${ }^{161}$ Furthermore, the Nigerian law also creates many legal technical strictures like locus standi, pre-action notice, limitation periods and causation, ${ }^{162}$ which are always used by lawyers to the offending parties to delay and frustrate the cases. ${ }^{163}$ A corollary to this factor is the judicial attitude of the Nigerian courts to environmental matters. ${ }^{164}$ While the courts of other developing countries like India, Thailand, Bangladesh among others have employed judicial activism and purposive interpretation tools to include environmental rights as part of substantive rights in their countries as well as adopting legally progressive procedures that have enhanced the delivery of environmental justice to the citizens, the Nigerian courts, especially the Supreme Court continue to consider environmental matters as tortious wrongs of nuisance and strict liability. ${ }^{165}$ This has hampered the development of environmental law jurisprudence in the country

161 Uwais, M., "Recent Development in Nigeria Strengthening Legal and Institutional Framework for promoting Environmental Management" (presentation, Global Judges Symposium on Sustainable Development and the Role of Law, Johannesburg, South Africa, 18-20 August, 2002).

162 Olanrewaju Fagbohun, Mournful Remedies, Endless Conflicts And Inconsistencies In Nigeria's Quest For Environmental Governance: Rethinking the Legal Possibilities for Sustainability (Lagos: NIALS, 2012), 62-76.

163 Aliyu Panti Isa, "Legal Remedies for Victims of Environmental Pollution in Nigeria" (Master's Thesis, ABU Zaria, Nigeria, 2014), 65-67.

164 Iroaganachi, N., "Environmental Nuisance Laws in Nigeria: Making them Effective for Sustainable Development" ATBU Journal of Environmental Technology 5, no. 1 (2012): 117-128.

165 Fagbohun, Mournful Remedies, Endless Conflicts And Inconsistencies In Nigeria's Quest For Environmental Governance, 62-76; C. I. N. Emelie, "The Judicial Approach To Environmental Protection In Nigeria: An Overview", Global Academic Group-Pristine, accessed May 4, 2016, http://www.globalacademicgroup.com/journals/pristine/THE\%20JUDICIAL\%2 0APPROACH $\% 20$ TO $\% 20$ ENVIRONMENTAL\%20PROTECTION\%20IN\%20 NIGERIA.pdf. 
and also contributes to lack of adequate awareness among the populace including the lawyers. ${ }^{166}$

Therefore, in order to effectively comply with the international standard of the principle of precautionary approach, the following suggestions are deemed necessary. First, the erection of masts should be allowed based on the precautionary stance of 'uncertainty of risk', that is targeted at minimising exposure rather than in the context of 'no risk'. This, therefore, makes it imperative to amend the EIA Act to take into cognisance the 'potentiality' of the hazardous effect of projects instead of the current 'severity' approach it adopts. Similarly, both the NCC Guidelines of 2009 and NESREA Regulations of 2011 should be effectively implemented. Thus, there should be regular auditing of the base stations to ensure that the standards approved are maintained constantly by the operators. Meanwhile, it is necessary to harmonise the guidelines and the regulation for adequate monitoring and implementation. ${ }^{167}$ This will remove clash of power and jurisdiction between the regulators and give them unity of purpose in protecting the environment.

Second, the government at all levels should be committed towards discharging their constitutional responsibility as enshrined in Chapter II of the Constitution of the Federal Republic of Nigeria 1999. The chapter contains the fundamental objectives and directives of social policy of the Federal Republic of Nigeria ${ }^{168}$ and this includes the duty of the government to provide uninterrupted electric power supply. But the failure of the government to fulfil the obligation has necessitated the incessant use of petrol and diesel fuelled generators, which contribute to noise and air pollution. Furthermore, the

166 Rufus Akpofurere Mmadu, "Judicial Attitude To Environmental Litigation And Access To Environmental Justice In Nigeria: Lessons From Kiobel" Afe Babalola University: Journal of Sustainable Development Law and Policy 2, no. 1 (2013): 149-170.

167 Although there is a report that both agencies are working towards harmonising some of their guidelines and standards, the outcome is yet to be known. See Akwaja, C., "NCC, NESREA Harmonise Guidelines as Telecoms Towers Hits 29,000", Leadership Newspaper, December 21, 2014, http://leadership.ng/business/396611/ncc-nesrea-harmonise-guidelines-telecomstowers-hits-29000; Osunnuyi, A., "Setback for BTS: Is NCC, NESREA power tussle really over?", National Mirror, December 22, 2014 http://nationalmirroronline.net/new/setback-for-bts-is-ncc-nesrea-power-tusslereally-over/.

168 These objectives are contained in sections $15-20$ of the Constitution of the Federal Republic of Nigeria 1999. 
constitution should be amended to recognise the matters contained in chapter II as being justiciable. This will enable the residents to have the power (locus standi) to enforce their right to healthy environment. As at present, the few enlightened residents, could if they feel aggrieved, only institute action under the general tort of nuisance, which is difficult to prove. There is need, therefore, to recognise environmental right as a fundamental right in Nigeria.

Third, the EIA Act should be amended to include telecommunication projects and take proper cognisance of the view and concerns of the public. Fourth, the Nigerian courts should be more proactive in their approach to environmental cases and adopt purposive interpretation tools that will project judicial awareness of existing social realities. In order to achieve this, the Nigerian Judicial Commission and the Nigerian Judicial Institute need to embark on continuous training for the judges especially the judges of the Federal High Court to properly equip them of the latest developments in the field of environmental and telecommunication law and science as well as public interest litigation. Finally, there is need for more involvement of non-governmental organisations in educating Nigerians about the high risks involved in the installation of telecommunication masts and base stations in residential areas. 